\title{
Molecular barcoding applied to the Mediterranean turtles biological matrices (Reptilia Cheloniidae)
}

\author{
Maria Flaminia Persichetti*, Viviana Giangreco, Antonio Gentile, Tiziana Lupo, Gabriele Ciaccio \& Santo \\ Caracappa
}

Istituto Zooprofilattico Sperimentale della Sicilia “A.Mirri” Via Gino Marinuzzi 3, 90129 Palermo, Italy

"Corresponding author, e-mail: flaminia.persichetti@izssicilia.it

ABSTRACT

KEY WORDS
Chelonia mydas (Linnaeus, 1758) together with Caretta caretta (Linnaeus, 1758) is the most representative Cheloniidae species in the Mediterranean basin. Currently, at the National Reference Centre in the "Istituto Zooprofilattico" of Sicily (Italy), damaged subjects are rehabilitated before they are released again. Clinical, physiological and molecular parameters were collected from each subject. We analysed 46 turtles which samples were collected. Species specific Cytochrome oxidase I sequences for the identification of marine turtle species were obtained. Barcoding is a new tool of classical taxonomy that allows the characterisation of living species and the differentiation of very morphologically similar species. It is a practical tool that can be used in cases of damaged samples and is also useful for taxonomical characterisation of specimen at immature development stages. In our region, in the centre of the Mediterranean area, we represent a reference centre for injured animals both stranded on the beach and captured in offshore.Turtles caught in fishing lines generally retain the fishing hooks in their throat or oesophagus, as visible by X-ray investigations. After the cure and samples collection, the animals are released into the sea. The polymorphisms could be related to the geographical distance of the turtles following different routes during their life. The large-scale sequencing of a single or few genes in taxonomic studies, denominated by species barcoding, aims at offering a practical method for species identification, as well as for providing insights into the evolutionary diversification of life.

Received 28.11.2019; accepted 19.12.2019; published online 20.12.2019

Proceedings of the 4th International Congress on Biodiversity "Man, Natural Habitats and Euro-Mediterranean Biodiversity", November 17th-19th, 2017 - Malta

\section{INTRODUCTION}

Three species of sea turtles lives in Mediterranean Sea: the leatherback turtle, Dermochelys coriacea (Vandelli, 1761), the green turtle, Chelonia mydas (Linnaeus, 1758), and the loggerhead turtle, Caretta caretta (Linnaeus, 1758). Two other species of sea turtles have been occasionally reported in the Mediterranean Sea: the hawksbill sea turtle, Eret- mochelys imbricata (Linnaeus, 1776), and the Kemp's ridley sea turtle, also called the Atlantic ridley sea turtle, Lepidochelys kempii (Garman, 1880) (Casale \& Margaritoulis, 2010). They are considered endangered, at regional and global level, and therefore it is protected by international laws and by numerous conventions.

Dermochelis coriacea is a Vulnerable species following IUCN (Wallace et al., 2013), Chelonia 
mydas is Endangered (Seminoff, 2004), and Caretta caretta is Vulnerable (Casale \& Tucker, 2017). Only Chelonia mydas and Caretta caretta breed in the Mediterranean basin and the nesting areas are concentrated in the eastern half of the Mediterranean Sea. These sea turtles are found, also, with particular frequency in some rest and feeding areas (like northern Adriatic Sea, Ionian Sea, Tunisia and Libya and Spanish coasts).

Chelonia mydas frequents the eastern Mediterranean with the nesting sites that are principally in Turkey, Cyprus, and Syria. Foranging areas are also in Greece and Libya and green turtles are found occasionally in the Adriatic Sea, Tunisia and other areas of the western Mediterrannean Sea.

Caretta caretta known also as common turtle, is the most widespread species and most representative Cheloniidae family species in the Mediterranean Sea, followed by Chelonia mydas (Dutton, 1996; Carreras et al., 2007; Casale \& Margaritoulis, 2010; Naro-Maciel et al., 2010). Caretta caretta is the only species of sea turtle nesting along the Italian coast. In the past, loggerhead sea turtles nesting was a regular phenomenon and relatively widespread along the coasts of the southern Italy, but over the last years, few cases of nesting have been recorded on the islands and coasts of Sicily, Sardinia, along the Ionian coast of Puglia and those of Basilicata and Calabria. However, nests are now considered sporadic or occasional, except for the Lampedusa and Linosa Islands. In the Italian coasts, their strandings are strongly influenced by the impact of massive fishing, the alteration of marine and coastal habitats and climate changes (Tamura et al., 2004). Currently, at the National Reference Centre for sea turtles located in the Istituto Zooprofilattico Sperimentale of Sicily (IZS Sicily, Italy), damaged subjects rescued along the Sicilian coasts are hospitalized, cured and freed again in the marine environment. Many exams are conducted in each subject including molecular parameters. Currently, there is a new tool to help track this highly migratory and endangered group of marine animals: DNA barcodes. DNA barcodes are short genetic sequences that efficiently distinguish species from each other, even if the samples from which the DNA is extracted are minute or degraded. DNA barcodes are relatively short segments of mitochondrial DNA. A region of the COI, or cox 1 gene (cytochrome $\mathrm{c}$ oxidase subunit 1) has been agreed upon by researchers as appropriate for barcoding, given that it is both highly variable and very specific. This portion of the genome mutates quickly enough to distinguish many closely related species but also slowly enough so that individuals within a species may have similar barcodes. The aim of the present study was to obtain species-specific COI barcode tags that can be used for identifying individually the marine turtle species studied. Indeed, the large-scale sequencing of a single or few genes in taxonomic studies, denominated the Barcode initiative, aims at representing a practical method for species identification, as well as for providing insights into the evolutionary diversification of life (Honda et al., 2002; Hudson \& Buhlmann, 2002; Hebert et al., 2003).

\section{MATERIAL AND METHODS}

Samples were collected from muscle tissue or blood of both dead and live turtles rescued. DNA was extracted with EZNA Tissue DNA kit (WVR) and spectroscopically quantized. The primers used for Cyt-b targeted PCR were 5'CTCACCAGACATCTCCATAGC-3' as forward and 5' GGGTTGTTTGAGCCTGTTTCGTG-3' as reverse amplifying a $545 \mathrm{bp}$ long fragment. PCR program was optimised as follow: $94^{\circ} \mathrm{C}$ for 8 minutes; $40 \mathrm{cy}$ cles of the repetitions $94^{\circ} \mathrm{C}$ for 50 seconds, $55^{\circ} \mathrm{C}$ for 50 seconds, $72^{\circ} \mathrm{C}$ for 1 minutes; finally $72^{\circ} \mathrm{C}$ for 7 minutes. PCR products were visualized on a $1 \%$

\begin{tabular}{|c|c|c||}
\hline $\begin{array}{c}\text { Number } \\
\text { of Subjects }\end{array}$ & BLAST code & SPECIES \\
\hline 52 & AY678314.1 & Caretta caretta \\
\hline 2 & AF385671.1 & Caretta caretta \\
\hline 51 & JX454984.1 & Caretta caretta \\
\hline 26 & KP256531.1 & Caretta caretta \\
\hline 8 & FR694649.1 & Caretta caretta \\
\hline
\end{tabular}

Table1. BLAST code relative to the identified subjets by mtDNA sequencing. 
agarose gel, purified and employed in sequencing analysis by Big Dye sequencing kit, (Applied Biosystems), according to the manufacturer instructions. After purification, the products were analyzed on Abi Prism 3130 Genetic Analyzer (Thermo). ClustalW2 software was employed for Gene Bank sequence data comparison and sequence multiple alignment for polymorphism detection. Data obtained in this work was used to create a barcode database for the Cyt-b gene sequence characterizing each turtle cured at the National Reference Centre for sea turtles (Istituto Zooprofilattico Sicilia Sicily, Palermo).

\section{RESULTS}

Out of 110 animals studied, all the sequences analyzed by Clustal W2 software ruled out a $99-100 \%$ sequence similarity to Caretta caretta species. Multiple alignment revealed a certain percentage of polymorphic SNPs, which could mark genetic variability through the various subject of the same species. The data here obtained allow to develop a database for the sequences barcoding. From the search for polymorphisms there is the possibility of identifying, on the one hand the species, on the other the small differences that may have a phylo-

\begin{tabular}{|c|c|c|}
\hline 1 & 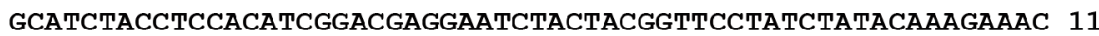 & 11 \\
\hline 8 & GСАTCTACCTCCACATCGGACGAGGAATCTACTACGGTTCCTATCTATACAAAGAAAC 10 & 02 \\
\hline 12 & GСАTCTACCTCCACATCGGACGAGGAATCTACTACGGTTCCTATCTATACAAAGAAAC 10 & 03 \\
\hline 14 & GСАTCTACCTCCACATCGGACGAGGAATCTACTACGGTTCCTATCTATACAAAGAAAC 10 & 03 \\
\hline 19 & GСАTCTACСTCCACATCGGACGAGGAATCTACTACGGTTCCTATCTATACAAAGAAAC 10 & 04 \\
\hline 6 & 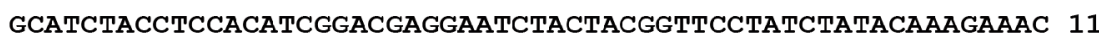 & 12 \\
\hline 20 & GСАTСТАССТССАСАTCGGACGAGGAATCTACTACGGTTCCTATCTATACAAAGAAAC 10 & 05 \\
\hline 16 & GСАTСTACCTCCACATCGGACGAGGAATCTACTACGGTTCCTATCTATACAAAGAAAC 10 & 03 \\
\hline 2 & GСАTСТАССТCСАCATCGGACGAGGAATCTACTACGGTTCCTATCTATACAAAGAAAC 11 & 12 \\
\hline 4 & GСАTCTACCTCCACATCGGACGAGGAATCTACTACGGTTCCTATCTATACAAAGAAAC 10 & 08 \\
\hline 3 & GСАTCTACCTCCACATCGGACGAGGAATCTACTACGGTTCCTATCTATACAAAGAAAC 11 & 11 \\
\hline 18 & GСАTСТАССТCСАСАTCGGACGAGGAATCTACTACGGTTCCTATCTATACAAAGAAAC 11 & 11 \\
\hline 10 & GСАTСТАССТССАСАTCGGACGAGGAATCTACTACGGTTCCTATCTATACAAAGAAAC 11 & 11 \\
\hline 11 & GСАTСТАССТССАСАTCGGACGAGGAATCTACTACGGTTCСТАССТАTACAAAGAAAC 11 & 15 \\
\hline 7 & GСАTСТАССТССАСАTCGGACGAGGAATCTACTACGGTTCCTATCTATACAAAGAAAC 11 & 12 \\
\hline 9 & GСАTCTACСTCCACATCGGACGAGGAATCTACTACGGTTCCTATCTATACAAAGAAAC 11 & 15 \\
\hline 15 & GСАTСТАCСTCCACATCGGACGAGGAATCTACTACGGTTCCTATCTATACAAAGAAAC 11 & 14 \\
\hline 23 & GСАTСТАССТCCACATCGGACGAGGAATCTACTACGGTTCCTATCTATACAAAGAAAC 11 & 13 \\
\hline 22 & 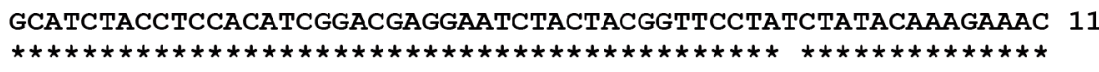 & 11 \\
\hline 1 & СТGAАATACCGGAATCATССТСТTACTACTAGTAATAGCCACCGCATTCGTAGGCTACGT & 171 \\
\hline 8 & СТGAАATACCGGAАTCATССТСТTACTACTAGTAАTAGCCACCGCATTCGTAGGCTACGT & 162 \\
\hline 12 & СТGAAATACCGGAATCATCCTСTTACTACTAGTAATAGCCACCGCATTCGTAGGCTACGT & 163 \\
\hline 14 & СТGAАATACCGGAATCATCСTСTTACTACTAGTAATAGCCACCGCATTCGTAGGCTACGT & 163 \\
\hline 19 & СТGAАATACCGGAATCATCСTСTTACTACTAGTAATAGCCACCGCATTCGTAGGCTACGT & 164 \\
\hline 6 & СТGAAATACCGGAATCATCСTСTTACTACTAGTAATAGCCACCGCATTCGTAGGCTACGT & 172 \\
\hline 20 & СТGAАATACCGGAATCATCСTСTTACTACTAGTAATAGCCACCGCATTCGTAGGCTACGT & 165 \\
\hline 16 & СТGAАATACCGGAATCATCСТСТTACTACTAGTAATAGCCACCGCATTCGTAGGCTACGT & 163 \\
\hline 2 & СТGAAATACCGGAATCATCСTСTTACTACTAGTAATAGCCACCGCATTCGTAGGCTACGT & 172 \\
\hline 4 & СТGAAATACCGGAATCATCСTСTTACTACTAGTAATAGCCACCGCATTCGTAGGCTACGT & 168 \\
\hline 3 & CTGAAATACCGGAATCATCCTCTTACTACTAGTAATAGCCACCGCATTCGTAGGCTACGT & 171 \\
\hline 18 & СTGAAATACCGGAATCATCCTCTTACTACTAGTAATAGCCACCGCATTCGTAGGCTACGT & 171 \\
\hline 10 & СТGAАATACCGGAATCATCCTCTTACTACTAGTAATAGCCACCGCATTCGTAGGCTACGT & 171 \\
\hline 11 & 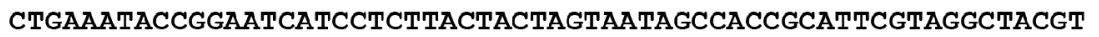 & 175 \\
\hline 7 & СТGAAATACCGGAATCATССТСТTACTACTAGTAATAGCCACCGCATTCGTAGGCTACGT & 172 \\
\hline 9 & СTGAAATACCGGAATCATCCTCTTACTACTAGTAATAGCCACCGCATTCGTAGGCTACGT & 175 \\
\hline 15 & СТGAАATACCGGAATCATCСТСТTACTACTAGTAATAGCCACCGCATTCGTAGGCTACGT & 174 \\
\hline 23 & СTGAAATACCGGAATCATCCTCTTACTACTAGTAATAGCCACCGCATTCGTAGGCTACGT & 163 \\
\hline 22 & CTGAAATACCGGA-TCATCCTCTTACTACTAGTAATAGCCACCGCATTCGTAGGCTACGT & 171 \\
\hline
\end{tabular}

Figure 1. Multiple alignment of sequences of some turtles examined. No significative polymorphic bases were found. 
genetic meaning useful for understanding the mechanisms of evolution and species. Moreover the analysis of the incidence of these polymorphisms can give indication on the mutational effects, on possible linkage maps, on the frequency of SNPs in the various subjects examined. However, from the sequence analysis among all the examined animals, no SNPs were found.

\section{DISCUSSION AND CONCLUSION}

As previously described in other animal species or in other geographical areas, the barcode is here proposed as a new tool of classical taxonomy which allows the characterization of living species as well as the differentiation of the individuals from the same origin and the others from a similar population within the same species. This practical and economical tool can also be used in cases of damaged samples and of immature state of development of the individual investigated including lost nests. The polymorphisms found in our results could be related to geographical distance of the turtles, which follow different routes during their, life and the Mediterranean Sea for the warm temperature during their reproductive activities. However, this preliminary data should be amplified in a larger population to better understand the migration faced by these animals into the Mediterranean basin as well as in other geographic areas of the world (Tamura et al., 2004). The potential for DNA barcoding applications is significant and often means that the species identity or geographic origin of a product is difficult to ascertain using conventional means. Barcoding items collected by wildlife management permit to track international trade in wildlife products. In addition, protected animals trapped can be identified through DNA barcoding. To assist in these efforts, barcode sequences from this study have been supplied to the Barcode of Life database and GenBank (Kocher et al., 1989), so that the data are freely available. DNA barcoding promises to be a powerful tool for species identification (Stoeckle, 2003; Stuart \& Parham, 2004; Vargas et al., 2009), and other conservation genetic applications in marine turtles, which are unique on the evolutionary tree of turtles for occupying the marine realm, and widely known for their extensive migrations. Species identification, one of the main goals of the DNA barcoding initiative, was successfully carried out using their COI sequences (Naro-Maciel et al., 2010). Distance based analysis of COI sequences consistently grouped members of the same species, although a complete sample was necessary for correct assignment using phenetic methods. There was no convincing evidence of cryptic species revealed in this research, a result that is concordant with many other genetic studies of marine turtles. In addition, the barcodes provided insight into population structure and history. However, hybridization is an important source of error for analyses relying solely on a mitochondrial marker, including in this group that is known to hybridize despite ancient separations.

Cytochrome c oxidase subunit I barcodes were obtained for each marine turtles, using discrete characters, more consistent with classical taxonomy than distance based methods. Importantly, the character based approach was reliable, no species diagnoses could be made if the query sequences did not contain the relevant diagnostic characters.

\section{REFERENCES}

Casale P. \& Margaritoulis D., 2010. Sea turtles in the Mediterranean: Distribution, threats and conservation priorities. Gland, Switzerland, IUCN, 294 pp.

Carreras C., Pascual M., Cardona L., Aguilar A., Margaritoulis D., Rees A., Turkozan O., Levy Y., Gasith A., Aureggi M. \& Khalil M., 2007. The genetic structure of the loggerhead sea turtle (Caretta caretta) in the Mediterranean as revealed by nuclear and mitochondrial DNA and its conservation implications. Conservation Genetics, 8: 761-775.

Casale P. \& Tucker A.D., 2017. Caretta caretta (amended version of 2015 assessment). The IUCN Red List of Threatened Species 2017: e.T3897A119333622. http://dx.doi.org/10.2305/IUCN.UK.2017-2.RLTS. T3897A119333622.en. Downloaded on 10 March 2019.

Dutton P.H., 1996. Proceedings of the international symposium on sea turtle conservation genetics Methods for collection and preservation of samples for sea turtle genetic studies 17-24.

Naro-Maciel E., Reid B., Fitzsimmons N.N., Le M., Desalle R. \& Amato G., 2010. DNA barcodes for globally threatened marine turtles: a registry approach to documenting biodiversità. Molecular Ecology Recources, 10: 252-263. https://doi.org/10.1111/j.17550998.2009.02747.x

Hebert P.D.N., Cywinska A., Ball S.L. \& deWaard J.R., 2003. Biological identifications through DNA bar- 
codes. Proceedings Biological sciences, 270: $313-$ 321. https://doi.org/10.1098/rspb.2002.2218

Honda M., Yasukawa Y., Hirayama R. \& Ota H., 2002. Phylogenetic relationships of the Asian box turtles of the genus Cuora sensu lato (Reptilia: Bataguridae) inferred from mitochondrial DNA sequences. Zoological Science, 19: 1305-1312. https://doi.org/10. 2108/zsj.19.13057.

Hudson R. \& Buhlmann K., 2002. Turtle rescue-turtle survival alliance executive summary. Turtle and Tortoise Newsletter, 6: 12-14.

Kocher T.D., Thomas W.K., Meyer A., Edwards S.V., Pääbo S., Villablanca F.X., Wilson A.C., 1989. Dynamics of mitochondrial DNA evolution in animals: amplification and sequencing with conserved primers. Proceedings of the National Academy of Sciences of the United States of America, 86: 61966200 .

Seminoff J.A., 2004. Chelonia mydas. The IUCN Red List of Threatened Species 2004: e.T4615A110 37468. http://dx.doi.org/10.2305/IUCN.UK.2004.
RLTS.T4615A11037468.en. Downloaded on 10 March 2019.

Stoeckle M., 2003. Taxonomy, DNA, and the Bar Code of Life. BioScience, 53: 796-797.

Stuart B.L. \& Parham J.F., 2004. Molecular phylogeny of the critically endangered Indochinese box turtle (Cuora galbinifrons). Molecular Phylogenetics And Evolution, 31: 164-177.

Tamura K., Nei M. \& Kumar S., 2004. Proceedings of the National Academy of Science Prospects for inferring very large phylogenies by using the neighborjoining method 101 11030-11035

Vargas S.M., Araújo F.C.F. \& Santos F.R., 2009. DNA barcoding of Brazilian sea turtles (Testudines). Genetics and Molecular Biology, 32: 608-612.

Wallace B.P., Tiwari M. \& Girondot M., 2013. Dermochelys coriacea. The IUCN Red List of Threatened Species 2013: e.T6494A43526147. http://dx. doi.org/1 0.2305/IUCN.UK.2013-2.RLTS. T6494A43526147.en. Downloaded on 10 March 2019. 
. 